30 Ramasamy A, Trabzuni D, Guelfi S, Varghese V, Smith C, Walker R, et al. Genetic variability in the regulation of gene expression in ten regions of the human brain. Nat Neurosci 2014; 17: 1418-28.

31 Ansari M, McKeigue PM, Skerka C, Hayward C, Rudan I, Vitart V, et al. Genetic influences on plasma CFH and CFHR1 concentrations and their role in susceptibility to age-related macular degeneration. Hum Mol Genet 2013; 22: 4857-69.

32 Fanous AH, Kendler KS. Genetic heterogeneity, modifier genes, and quantitative phenotypes in psychiatric illness: searching for a framework. Mol Psychiatry 2005; 10: 6-13.

33 Power RA, Keers R, Ng MY, Butler AW, Uher R, Cohen-Woods S, et al. Dissecting the genetic heterogeneity of depression through age at onset. Am J Med Genet B 2012; 159B: 859-68.

34 Klein RJ, Zeiss C, Chew EY, Tsai JY, Sackler RS, Haynes C, et al. Complement factor $\mathrm{H}$ polymorphism in age-related macular degeneration. Science 2005; 308: 385-9.

35 Rodriguez de Cordoba S, Esparza-Gordillo J, Goicoechea de Jorge E, Lopez-Trascasa M, Sanchez-Corral P. The human complement factor $\mathrm{H}$ : functional roles, genetic variations and disease associations. Mol Immunol 2004; 41: 355-67.

36 Chen $\mathrm{H}, \mathrm{Yu}$ KD, Xu GZ. Association between variant $\mathrm{Y} 402 \mathrm{H}$ in age-related macular degeneration (AMD) susceptibility gene $\mathrm{CFH}$ and treatment response of AMD: a meta-analysis. PLoS One 2012; 7: e42464.
37 Raychaudhuri S, Iartchouk O, Chin K, Tan PL, Tai AK, Ripke S, et al. A rare penetrant mutation in $\mathrm{CFH}$ confers high risk of age-related macular degeneration. Nat Genet 2011; 43: 1232-6.

38 Hasler G, Northoff G. Discovering imaging endophenotypes for major depression. Mol Psychiatry 2011; 16: 604-19.

39 Jonsen A, Nilsson SC, Ahlqvist E, Svenungsson E, Gunnarsson I, Eriksson KG, et al. Mutations in genes encoding complement inhibitors CD46 and CFH affect the age at nephritis onset in patients with systemic lupus erythematosus. Arthritis Res Ther 2011; 13: R206.

40 Noris M, Caprioli J, Bresin E, Mossali C, Pianetti G, Gamba S, et al. Relative role of genetic complement abnormalities in sporadic and familial aHUS and their impact on clinical phenotype. Clin J Am Soc Nephro 2010; 5: 1844-59.

41 Donoso LA, Vrabec $\mathrm{T}$, Kuivaniemi $\mathrm{H}$. The role of complement factor $\mathrm{H}$ in agerelated macular degeneration: a review. Surv Ophthalmol 2010; 55: 227-46.

42 Frank MG, Frank JLW, Hendricks SE, Burke WJ, Johnson DR. Age at onset of major depressive disorder predicts reductions in NK cell number and activity. J Affect Disorders 2002; 71: 159-67.

43 Massat I, Souery D, Del-Favero J, Nothen M, Blackwood D, Muir W, et al. Association between COMT (Val158Met) functional polymorphism and early onset in patients with major depressive disorder in a European multicenter genetic association study. Mol Psychiatry 2005; 10: 598-605.

\section{psychiatry in history}

\section{An 18th-century view of demonomania. 2: Vampirism - explanation}

\section{Fiona Subotsky}

Martinus Martini considers that a supernatural explanation is an easy way out for complex phenomena, and develops more naturalistic explanations. First, the symptoms of a vampire attack are 'sudden awakening, anxiety, oppression of the chest, difficulty breathing, a sensation of suffocation, and terror ... Shortly afterwards they breathe their last.' He considers this very similar to a nightmare except for the fatal result, and wonders why people imagine that they have been attacked by the dead. His explanation is that:

When a rumour of vampire attack spreads to the crowd ... the terrifying idea occupies people's minds the whole day because they fear immediate death ... And when such a highly fixed idea is manifest in sleep, a situation in which imagination alone thrives, all senses are silent and are inactive, and all movements of the body are suspended with the exception of the vital powers, so it must be as vivid as that which is produced by sensations. This agreed, it is not inappropriate for people to say that they have seen this or that dead person and to have been oppressed by them, while at the same time pressure of the chest and constriction of the throat by muscles contracted in spasm take hold.

Next has to be considered why people die. The presence of acute disease is likely, and added to this are the effects of fear:

a man suddenly with less will, a painful sensation as if the chest is compressed, palpitation of the heart, great difficulty in respiration and the whole body is convulsed and grows pale because of spasms of the muscles. In the greatest terror al these things are increased.

Then there is the question of why the bodies do not decompose: Martini points out that the environment of the grave affects the rate of decomposition, which is likely to be slowed if the surroundings are dry, cold or nitrous. Decomposition is more likely if the body itself is moist rather than dry: 'And so the bodies of scurvy sufferers decay sooner than those with typhoid, and those who have suffered with putrid fever [typhus], than those who have died from the emaciation of old age'.

Why do the hair and nails grow?

Many doctors are united in the opinion that this is either a fallacy of the senses, because . . . as the smallest vessels of the superficial body collapse, the flesh shrinks ... and so the roots of nails and hair become more prominent and look longer. Or, such dead are buried with longer hair, about which at the time nobody was concerned.

I have abbreviated Martini's comments, but, as he says: 'Let this brief contemplation suffice for the more noble mind, so that it may condemn the superstition about Vampires as chimeras'

Part one, 'Introduction' and part two, 'Stories' were published in the March and April issues of the BJPsych. 